\title{
The expression of COX-2 and iNOS in ethanol and aspirin induced gastric ulcer rat models
}

\author{
Sherly Usman ${ }^{1}$, Yustina Andwi Ari Sumiwi ${ }^{1}$, Dewi Kartikawati Paramita ${ }^{1 *}$ \\ ${ }^{1}$ Department of Histology, Faculty of Medicine, Public Health and Nursing, Universitas \\ Gadjah Mada, Yogyakarta, Indonesia
}

DOI: http://dx.doi.org/10.19106/JMedScie/005003201807

\section{ABSTRACT}

Aspirin or ethanol induced gastric ulcer rat models are the most frequently used in studies. Aspirin and ethanol induced gastric ulcers through different pathways involving COX-2 and iNOS. The aim of this study was to examine the expression of COX-2 and iNOS in gastric ulcer rat model induced by ethanol and aspirin. Twenty-one Sprague Dawley rats were divided into 7 groups i.e. control group $(C A)$, ethanol $1^{\text {st }}$ day $\left(E D_{1}\right)$, ethanol $3^{\text {rd }}$ day $\left(E D_{3}\right)$, ethanol $5^{\text {th }}$ day $\left(E D_{5}\right)$, aspirin $4^{\text {th }}$ day $\left(A D_{4}\right)$, aspirin $6^{\text {th }}$ day $\left(A D_{6}\right)$, and aspirin $8^{\text {th }}$ day $\left(A D_{8}\right)$. Oral administration of aspirin was at $200 \mathrm{mg} / \mathrm{kgBW}$ and the $100 \%$ ethanol at $1 \mathrm{~mL} / 200 \mathrm{gBW}$. Macroscopic and microscopic observations were done to examine the gastric mucosal damage, COX-2 and iNOS expressions. Severe gastric ulcers were observed in ED, and $A D_{4}$ groups and mild gastric mucosal damage was observed in $E D_{3}, E D_{5}, A D_{6}$ and $A D_{8}$ groups. Microscopically, light erosion was shown by the $C A$ and $A D_{8}$ groups. Erosion was also shown by $\mathrm{ED}_{3}, \mathrm{ED}_{5}$, and $\mathrm{AD}_{6}$ groups. The most severe damage with ulcers and heavier bleeding were shown by the $E D_{1}$ and $A D_{4}$ groups. Weak COX-2 expression was found in the CA, while the highest COX-2 expression was found in the ED. The iNOS expression in the ethanol groups was still increasing until the $5^{\text {th }}$ day $\left(E D_{5}\right)$. In the aspirin groups, it reached the peak on the $3^{\text {rd }}$ day $\left(A D_{6}\right)$, and already declined on the $5^{\text {th }}$ day $\left(A D_{8}\right)$. In conclusion, the damage process of ethanol induced gastric ulcer occurred faster than that by aspirin. The highest COX-2 expression in the ethanol and aspirin groups were shown at the onset begin. iNOS expression in ethanol induced ulcer groups still increased until the $5^{\text {th }}$ day, while in the aspirin induced ulcer groups already declined in the $5^{\text {th }}$ day.

\section{ABSTRAK}

Tikus model ulkus lambung yang diinduksi oleh aspirin atau etanol adalah model yang paling sering digunakan dalam penelitian. Ulkus lambung yang diinduksi aspirin mempunyai jalur pathogenesis yang berbeda dengan yang diinduksi oleh etanol, namun keduanya melibatkan COX-2 dan iNOS. Tujuan penelitian ini adalah mengkaji ekspresi COX-2 dan iNOS pada tikus model ulkus lambung yang diinduksi oleh ethanol dan aspirin. Dua puluh satu tikus Sprague Dawley dibagi menjadi 7 yaitu kelompok kontrol $(C A)$, etanol hari pertama $\left(E D_{1}\right)$, etanol hari ketiga $\left(E D_{3}\right)$, etanol hari kelima $\left(E D_{5}\right)$, aspirin hari keempat $\left(A D_{4}\right)$, aspirin hari keenam $\left(A D_{6}\right)$, dan aspirin hari kedelapan $\left(A D_{8}\right)$. Perlakuan diberikan secara oral, dengan dosis aspirin sebesar $200 \mathrm{mg} / \mathrm{kgBB}$ dan dosis $100 \%$ etanol sebesar $1 \mathrm{~mL} / 200 \mathrm{gBB}$. Pengamatan makroskopis dan mikroskopis dilakukan untuk menilai kerusakan mukosa lambung, ekspresi COX-2 dan iNOS. Ulkus lambung berat terlihat pada kelompok $E D_{1}$ dan $\mathrm{AD}_{4}$ dan kerusakan mukosa lambung ringan terlihat pada kelompok $E D_{3}, E D_{5}, A D_{6}$ and $A D_{8}$. Secara mikroskopis, erosi ringan terlihat pada kelompok $C A$ dan $A D_{8}$. Erosi juga terlihat kelompok $E D_{3}, E D_{5}$, dan $A D_{6}$. Kerusakan paling berat dengan ulkus dan pendarahan terlihat pada kelompok $E D_{1}$ dan $A D_{4}$. Ekspresi COX2 lemah terlihat pada kelompok CA, sedangkan ekspresi terkuat terlihat pada kelompok $E_{1}$. Ekspresi iNOS pada kelompok etanol masih mengalami peningkatan sampai hari 
kelima $\left(E D_{5}\right)$, sedangkan pada kelompok aspirin ekspresi iNOS mencapai puncak pada hari ketiga $\left(A D_{6}\right)$, dan telah menurun pada hari kelima $\left(A D_{8}\right)$. Dapat disimpulkan proses kerusakan mukosa lambung yang diinduksi oleh etanol terjadi lebih cepat dibandingkan yang diinduksi oleh aspirin. Ekspresi COX-2 tertinggi pada kelompok aspirin dan etanol tampak pada saat mulai terjadi ulkus. Ekspresi iNOS ulkus yang diinduksi etanol masih meningkat sampai hari ke-5, sedangkan pada yang diinduksi aspirin telah menurun pada hari ke-5.

Keywords : gastric mucosal damage - gastric ulcer - aspirin - ethanol - COX-2 - iNOS

\section{INTRODUCTION}

Gastric ulcer is the most prevalent digestive problem in clinical examination and affects 5 to $10 \%$ of people during their life. ${ }^{1}$ Gastric ulcer is a complex, multifactorial disease and its aetiology not fully understood. It appears as a pathologic lesion in the digestive tract exposed to ulcerogenic agents. Gastric ulcer is considered as a result of an imbalance between invasive and defensive factors. ${ }^{2}$ Bicarbonate and prostaglandin (PG) are considered as the defensive factors, whereas ethanol and aspirin as the external invasive factors. ${ }^{2,3}$

Ethanol- and aspirin-induced gastric ulcer are the most common experimental models. ${ }^{4}$ In daily life, people use aspirin as NSAID drugs, which are usually important for cardiovascular and cerebrovascular therapy. ${ }^{5}$ Alcohol consumption is also common for people in several parts of the world. Previous studies proved that ethanol and aspirin can induce the production of inflammatory mediators, such as tumour necrosis factor alpha (TNF- $\alpha)$ and reduce the production of $\mathrm{PG}$. When the condition continuously occurs, it can induce gastric ulcers. Ethanol induced gastric damage develops by different mechanisms compared to the one induced by aspirin.

Gastric lesions caused by aspirin occur due to the cyclooxygenase (COX) inhibition. Cyclooxygenase consists of cyclooxygenase-1 (COX-1) and cyclooxygenase-2 (COX-2). ${ }^{6,7}$ The use of low dosage aspirin inhibits COX-1 production resulting in the reduction of PG production. This condition will disrupt the blood flow in the mucosa of gastric resulting in the production of inflammatory mediators, such as TNF- $\alpha$ and interleukin-1 beta (IL-1 $\beta$ ). Moreover, these conditions will induce COX-2 production resulting in the production of more $\mathrm{PG}$ for the mucosa healing process. ${ }^{8}$

Ethanol induced gastric mucosa damage is caused by free radicals, such as reactive oxygen species (ROS), the by-products of metabolism. ${ }^{9}$ Accumulation of ROS induces oxidative stress. The imbalance of ROS and antioxidants will trigger scavenger enzyme dysfunction. ${ }^{10}$ Ethanol has a robust and easy penetration nature to the mucosa gastric layers. ${ }^{9}$ Disturbance of the integrity of gastric mucosa will induce the production of gastro-protective mucosa agents, such as nitric oxide (NO). Ethanol can inhibit the production of $\mathrm{NO}$, which results in more severe gastric mucosa damage. ${ }^{9}$ The gastric mucosa damage can induce inducible nitric oxide (iNOS) activity to produce NO again for healing mucosa. ${ }^{11}$

In order to confirm and to understand the different mechanisms of gastric ulcers induced by ethanol and aspirin, this study aimed to examine the gastric mucosal damage caused by ethanol and aspirin. Furthermore, this study purposed to examine the COX-2 and iNOS expression on the tissue of gastric ulcer rat models induced by ethanol and aspirin.

\section{MATERIALS AND METHODS}

\section{Animals, treatments and termination}

This experimental study used post-test only control group. Twenty-one healthy adult male Sprague Dawley rats with $200 \mathrm{~g}$ weight were used in this study. They were 
adapted to the standard laboratory conditions for one week. The rats received pellets, were allowed free access to water during the experiment, and they were kept under controlled environment of 12-hour light-dark cycle. The animals were numbered, weighed and divided into seven groups of 3 (TABLE 1). The dosage and termination time of the rats in ethanol groups were determined according to the study by Al-Qaraghuly. ${ }^{12}$

TABLE 1. The animal groups, treatment and termination time

\begin{tabular}{lcc}
\hline Groups & $\begin{array}{l}\text { I n d u c t i o n } \\
\text { (treatment) type }\end{array}$ & $\begin{array}{l}\text { Termination time } \\
\text { after induction }\end{array}$ \\
\hline $\mathrm{CA}$ & Aquadest & $1^{\text {st }}$ day \\
$\mathrm{ED}_{1}$ & Ethanol $100 \%$ & $1^{\text {st }}$ day \\
$\mathrm{ED}_{3}$ & Ethanol $100 \%$ & $3^{\text {rd }}$ day \\
$\mathrm{ED}_{5}$ & Ethanol $100 \%$ & $5^{\text {th }}$ day \\
$\mathrm{AD}_{4}$ & Aspirin & $4^{\text {th }}$ day \\
$\mathrm{AD}_{6}$ & Aspirin & $6^{\text {th }}$ day \\
$\mathrm{AD}_{8}$ & Aspirin & $8^{\text {th }}$ day \\
\hline
\end{tabular}

Note: Aspirin dosage was $200 \mathrm{mg} / \mathrm{kg} \mathrm{BW}$, ethanol dosage was $1 \mathrm{~mL} / 200 \mathrm{~g} \mathrm{BW}$

After the adaptation, the rats were fasted for 24 hours and followed by the induction and then were euthanized according to the termination time as seen in TABLE 1 .

\section{Gastric organ uptake, macroscopic observation of gastric ulcer and slide preparation}

The stomachs of the rats were removed, opened along the greater curvature, rinsed with saline, and examined for the severity and number of mucosal gastric lesions. The lesions were blindly examined according to the appearance and evaluated by a modified scoring system. ${ }^{11}$ The score was evaluated by two trained observers. The criteria of the mucosal damage and the scoring can be seen in TABLE 2. The mean scores for each group were calculated.

TABLE 2. Criteria and score of gastric mucosa damage macroscopic

\begin{tabular}{cc}
\hline Score & Criteria \\
\hline 0 & Normal stomach \\
1 & Red coloration \\
2 & Spot ulcer \\
3 & Bleeding \\
4 & Ulcer with bleeding/deep ulcer \\
5 & Perforation \\
\hline
\end{tabular}

The tissues with gastric ulcer were sliced at $1 \mathrm{~cm}$ thickness, fixed in buffered formalin for maximum 24 hours and processed for paraffin embedding using standard protocol. ${ }^{28}$ The formalin fixed paraffin embedded (FFPE) tissues were sliced at $6 \mu \mathrm{m}$ thick for haematoxylin eosin (HE) staining and at $4 \mu \mathrm{m}$ thick for evaluating COX-2 and iNOS expression by immune histochemistry (IHC). The COX-2 and iNOS expressions were examined in 3 slides for each subject with $100 \mu \mathrm{m}$ distance between each slide.

\section{Mucosal damage scoring}

The mucosal injury was examined under light microscopy by two blinded examiners. The examination was quantified according to a two-step scoring system (length score and depth score $)^{12}$ as seen in TABLE 3 and 4. The total microscopic score resulted from the sum of the two partial scores and ranged from 0-6. Each sample was observed in 5 views foreach group by using microscope at 100x and 400x magnification. 
TABLE 3. Criteria and the length of damage area score

\begin{tabular}{cl}
\hline Score & \multicolumn{1}{c}{ Criteria } \\
\hline 0 & no lesion \\
1 & lesion involving $1 \%-10 \%$ \\
2 & lesion involving $11 \%-20 \%$ \\
3 & lesion involving $>20 \%$ \\
\hline
\end{tabular}

TABLE 4. Score and criteria of deep lesion in gastric mucosa

\begin{tabular}{|c|c|}
\hline Score & Criteria \\
\hline 0 & no change \\
\hline 0.5 & Superficial erosion \\
\hline 1 & ulcer involving one internal third of the mucosa \\
\hline 2 & $\begin{array}{l}\text { ulcer involving the two internal thirds of the } \\
\text { mucosa }\end{array}$ \\
\hline 3 & $\begin{array}{l}\text { ulcer involving almost the entire mucosal } \\
\text { thickness }\end{array}$ \\
\hline
\end{tabular}

\section{IHC for COX-2 and iNOS expression and the scoring}

The IHC was performed according to the manual of the kit (Bio Care Medical STUHRP700 H, L10). The dilution of antibody anti COX-2 (Abcam ab15191) was 1:200 and antibody anti iNOS (Abcam ab15323) was 1:100 with the incubation time for both antibodies was $24 \mathrm{hrs}$ in $4^{\circ} \mathrm{C}$. After the IHC procedure, the slides were counterstained with haematoxylin (Meyers, Inc.), and then dehydrated and mounted.

The slides were examined under light microscopy for COX-2 and iNOS; and scored according to the modification of Allred score protocol. ${ }^{13}$ Cells with immunoreactivity toward antibody anti-COX-2 appeared as brown stained cells in the cytoplasm andiNOS appeared as brown stained cells in the cytoplasm and nucleus. The calculation of COX-2 and iNOS expressions were done semi-quantitatively. Calculation of proportion of positive cells was done under light microscope at 400x magnification at 5 different fields of view. The proportion and intensity score can be seen in TABLE 5. The final score was the summing up of the proportion and intensity score. The minimum score is showed in TABLE 6 . The observations were done by 2 blinded observers. The results were documented by using Optilab ${ }^{\circledR}$.

Table 5. Proportion score and intensity score

\begin{tabular}{ll}
\hline Proportion score & Intensity score \\
\hline $0=$ no positive immunostaining & $0=$ negative \\
$1=<1 \%$ & $1=$ weak \\
$2=1-10 \%$ & $2=$ moderate \\
$3=10-33 \%$ & $3=$ strong \\
$4=33-66 \%$ & \\
$5=>66 \%$ & \\
\hline
\end{tabular}

TABLE 6. Interpretation of final score of COX-2 and iNOS expression

\begin{tabular}{lc}
\hline Final score & Interpretation \\
\hline $0-2$ & Negative \\
$>2-5$ & Weak positive \\
$>5-8$ & Strong positive \\
\hline
\end{tabular}

\section{Statistical analysis}

The data were initially analysed by using Shapiro-Wilk test and the results showed that the data was not in normal distribution. Therefore, to analyse the mean difference, it was analysed by using Kruskal-Wallis test, and further by using Mann Whitney test.

\section{RESULTS}

The dosage of ethanol used in this study was $1 \mathrm{~mL} / 200 \mathrm{~g}$ BW of $100 \%$ ethanol. Due to the high dosage of ethanol, the ulcer came up on the first day after induction. For the aspirin induced ulcer, the determination of the dosage was according to the preliminary study. The preliminary study was performed based on several previous studies, which mentioned that the dosage for ulcer induction is $200-400 \mathrm{mg} / \mathrm{kgBW} .^{6,14,15}$ Termination time 
for aspirin treatment in the previous research was done on the first and third days after treatment. ${ }^{6,15}$

\section{Preliminary study on aspirin induction}

Two aspirin dosages were used in the preliminary study, $200 \mathrm{mg} / \mathrm{kgBW}$ and $400 \mathrm{mg} / \mathrm{kgBW}$. The termination time for $200 \mathrm{mg} / \mathrm{kgBW}$ were days 3,4 , and 5 after treatment; and for $400 \mathrm{mg} / \mathrm{kgBW}$ were days 1,2 , and 3 after treatment. The results showed that aspirin at $400 \mathrm{mg} / \mathrm{kgBW}$ did not cause any ulcer at all. For the aspirin at $200 \mathrm{mg} / \mathrm{kgBW}$, the ulcer began to come up on the $4^{\text {th }}$ day, therefore, the real experiment for aspirin used dosage at $200 \mathrm{mg} / \mathrm{kgBW}$ with termination time on the $4^{\text {th }}, 6^{\text {th }}$ and $8^{\text {th }}$ days after treatment.

\section{Assessment of gastric mucosal damage}

Macroscopically, assessment of gastric mucosal damage was done by observing the characteristics that were categorized and rated into normal (0), red colour (1), spot ulcer (2), bleeding (3), ulcer with bleeding (4), and perforation (5). After the stomach was removed and opened along the greater curvature, the macroscopic conditions of the gastric mucosa of the rats for each group can be seen in FIGURE 1.

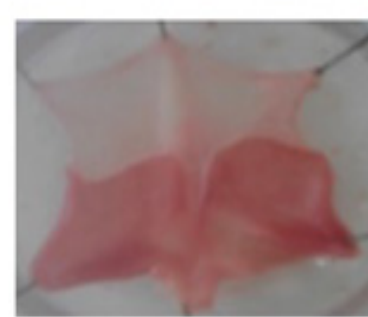

A

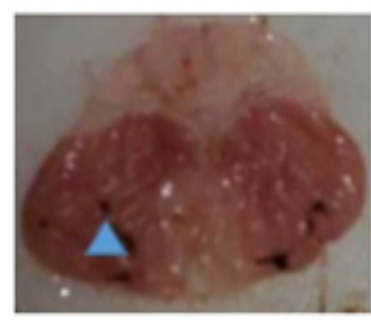

E

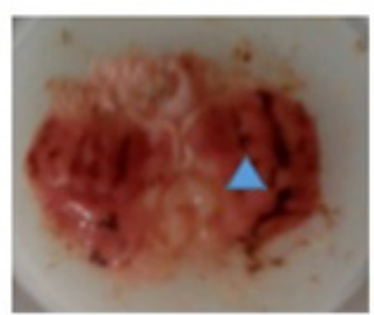

B

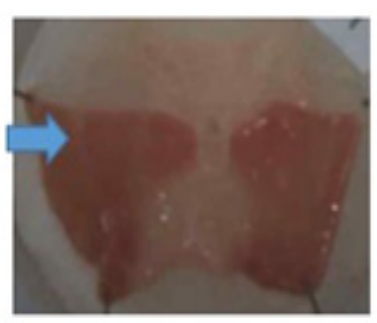

$\mathbf{F}$

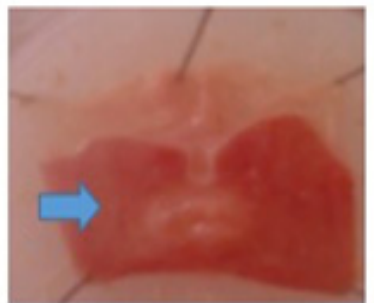

C

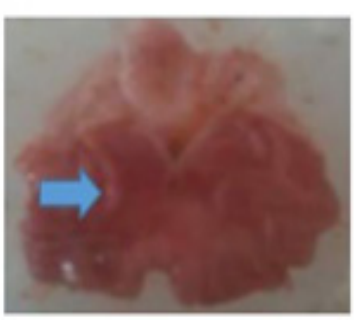

G

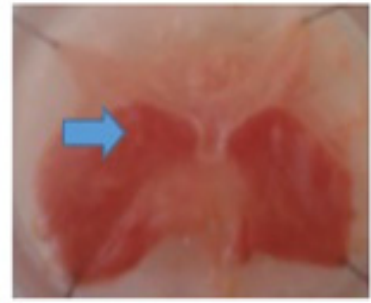

D

FIGURE 1. Macroscopic gastric mucosal damage, Normal gastric was shown in control group (CA); mucosal damage in the form of spot ulcer was shown in ethanol $3^{\text {rd }}$ day $\left(\mathrm{ED}_{3}\right)(\mathrm{C})$, ethanol $5^{\text {th }}$ day $\left(\mathrm{ED}_{5}\right)(\mathrm{D})$, aspirin $6^{\text {th }}$ day $\left(\mathrm{AD}_{6}\right)(\mathrm{F})$ and aspirin $8^{\text {th }}$ day $\left(\mathrm{AD}_{8}\right)(\mathrm{G})$; severe mucosal damage (ulcer with bleeding) was shown in ethanol $1^{\text {st }}$ day $\left(\mathrm{ED}_{1}\right)(\mathrm{B})$ and aspirin $4^{\text {th }}$ day $\left(\mathrm{AD}_{4}\right)(\mathrm{E})$.

Normal gastric mucosa can be seen in the control group (CA). All of the rats in the group showed normal gastric mucosa. Most of the rats from several groups showed mild gastric mucosal damage with spot ulcers.
Most of the rats from groups $\mathrm{ED}_{1}$ and $\mathrm{AD}_{4}$ showed severe gastric mucosal damage (ulcer with bleeding or exsanguinations) (TABLE 7). 
TABLE 7. Score of gastric mucosal damage macroscopically

\begin{tabular}{cc}
\hline Group & Modus \\
\hline $\mathrm{CA}$ & 0 \\
$\mathrm{ED}_{1}$ & 4 \\
$\mathrm{ED}_{3}$ & 2 \\
$\mathrm{ED}_{5}$ & 2 \\
$\mathrm{AD}_{4}$ & 4 \\
$\mathrm{AD}_{6}$ & 2 \\
$\mathrm{AD}_{8}$ & 2 \\
\hline
\end{tabular}

Interpretation: $0=$ normal, $1=$ red colour, $2=$ spot ulcer, $3=$ bleeding, $4=$ ulcer with bleeding, $5=$ perforation

Microscopically, the assessment of gastric mucosal damage was done by summing up the score of percentage of lesion area and ulcer depth which can be seen in TABLES 3 and 4 . Gastric mucosal damage could be in the form of erosion or ulcer. Erosion is epithelial lesion of gastric mucosa; and ulcer is the absence of gastric mucosa (epithelium, lamina propria and muscularis mucosa) and sometimes the lesion could reach the tunica muscularis.

The microscopic score of gastric mucosal damage can be seen in TABLE 8 . The lowest mean of the score was $1.000 \pm$ 0.866 , which appeared in the $\mathrm{CA}$ and $\mathrm{AD}_{8}$ groups, that shown as erosion (FIGURES $2 \mathrm{~A}$ and $2 \mathrm{G})$. The erosion also appeared in the $\mathrm{ED}_{3}, \mathrm{ED}_{5}$, and $\mathrm{AD}_{6}$ groups, but the lesion was deeper and accompanied by low level of bleeding (FIGURES 2C, 2D, and 2F). Compared to the $\mathrm{CA}$ and $\mathrm{AD}_{8}$ group, the mean of the score of gastric mucosal damage was higher (1.833 \pm 0.577$)$. The most serious damage appeared in the $\mathrm{ED}_{1}$ and $\mathrm{AD}_{4}$ groups. These groups also showed ulcers with heavier bleeding (FIGURES $2 \mathrm{~B}$ and 2E). The highest mean score of gastric mucosal damage was also shown by these groups (4.667 \pm 0.577 for $E D_{1}$ and $4.000 \pm 1.000$ for $\left.\mathrm{AD}_{4}\right)$. Kruskal Wallis test found that there was difference in the means in the treatment groups $(p=0.000 ; p<0.05)$. Further tests using Mann Whitney found that the mean difference can be seen in all of the groups compared to the CA except $\mathrm{AD}_{8}$ (TABLE 8).

TABLE 8. Mean of the microscopic score of gastric mucosal damage

\begin{tabular}{cc}
\hline Group & Mean score \pm SD \\
\hline $\mathrm{CA}$ & $1.000 \pm 0.866$ \\
$\mathrm{ED}$ & $4.667 \pm 0.577$ \\
$\mathrm{ED}_{3}$ & $1.833 \pm 0.577$ \\
$\mathrm{ED}_{5}$ & $1.833 \pm 0.577$ \\
$\mathrm{AD}_{4}$ & $4.000 \pm 1.000$ \\
$\mathrm{AD}_{6}$ & $1.833 \pm 0.577$ \\
$\mathrm{AD}_{8}$ & $1.000 \pm 0.866$ \\
\hline
\end{tabular}

Interpretation: severity of gastric mucosa microscopically was 0.5 to 6 (mild to severe) 


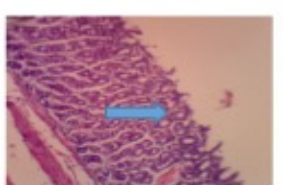

A1

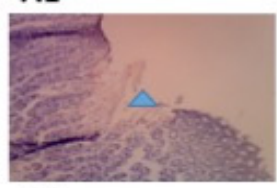

B1

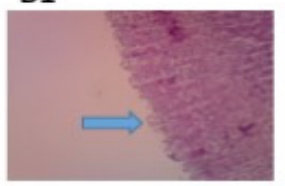

C1

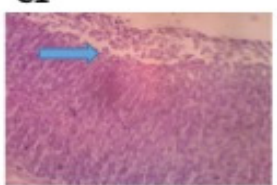

D1

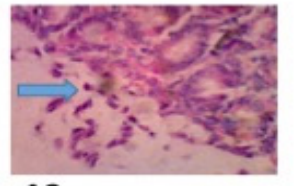

A2

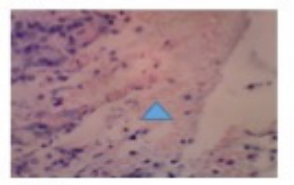

B2

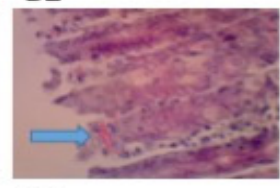

C2

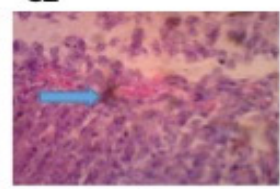

D2

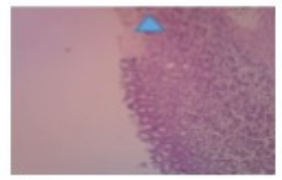

E1

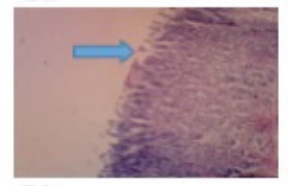

F1

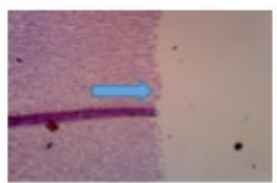

G1

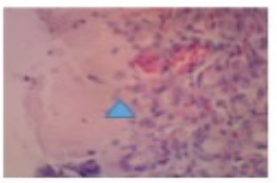

E2

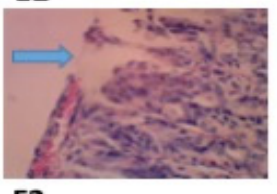

F2

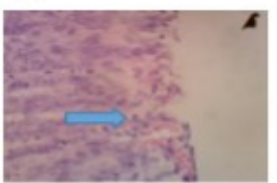

G2

FIGURE 2. Microscopic appearance of gastric mucosal damage. A. control group (CA); B. ethanol $1^{\text {st }}$ day group $\left(\mathrm{ED}_{1}\right)$; C. ethanol $3^{\text {rd }}$ day group $\left(\mathrm{ED}_{3}\right)$; D. ethanol $5^{\text {th }}$ day group $\left(\mathrm{ED}_{5}\right) ; \mathrm{E}$. aspirin $4^{\text {th }}$ day group $\left(\mathrm{AD}_{4}\right) ; \mathrm{F}$. aspirin $6^{\text {th }}$ day group $\left(\mathrm{AD}_{6}\right)$; G. aspirin $6^{\text {th }}$ day group. CA and $\mathrm{AD}_{8}$ shown the lightest erosion ( $2 \mathrm{~A}$ and $\left.2 \mathrm{G}\right) . \mathrm{ED}_{3}, \mathrm{ED}_{5}$ and $\mathrm{AD}_{6}$ shown deeper erosion with light bleeding $(2 \mathrm{C}, 2 \mathrm{D}$ and $2 \mathrm{~F})$. $\mathrm{ED}_{1}$ and $\mathrm{AD}_{4}$ shown ulcer with heavier bleeding. The number after alphabet in the figure means: 1 for low magnification and 2 for high magnification. The ulcer showed by arrow head and the erosion showed by arrow.

\section{COX-2 expression}

The mean score of COX-2 expression can be seen in TABLE 9. The data showed abnormal distribution after Shapiro Wilktest. In order to test the mean difference among the groups, Kruskal Wallistest was performed and showed that some of the groups have different means of COX-2 expression score $(p=0.048 ; p<0.05)$. Further, Mann Whitney tests were done to see the differences among the groups.
TABLE 9. COX-2 expression on induced gastric mucosal damage tissue

\begin{tabular}{cc}
\hline Group & Mean score \\
\hline $\mathrm{CA}$ & $2.667 \pm 0.577$ \\
$\mathrm{ED}_{1}$ & $6.000 \pm 0.000$ \\
$\mathrm{ED}_{3}$ & $5.667 \pm 0.577$ \\
$\mathrm{ED}_{5}$ & $5.334 \pm 0.577$ \\
$\mathrm{AD}_{4}$ & $6.000 \pm 0.000$ \\
$\mathrm{AD}_{6}$ & $5.334 \pm 0.577$ \\
$\mathrm{AD}_{8}$ & $5.000 \pm 0.000$ \\
\hline
\end{tabular}

Interpretation: $0-2=$ negative expression, $>2-5=$ weak expression, $>5-8=$ strong expression 
The $\mathrm{CA}$ and $\mathrm{AD}_{8}$ groups showed weak COX-2 expression and the other groups shown strong expression (FIGURE 3). Mann Whitney tests shown that the mean score of COX-2 expression in the CA group was lowest and significantly different from all of the treatment groups. The $\mathrm{ED}_{1}$ and $\mathrm{AD}_{4}$ groups had the highest mean score of COX-2 expression compared to $\mathrm{ED}_{3}, \mathrm{ED}_{5}, \mathrm{AD}_{6}$ and $\mathrm{AD}_{8}$ (TABLE 9).

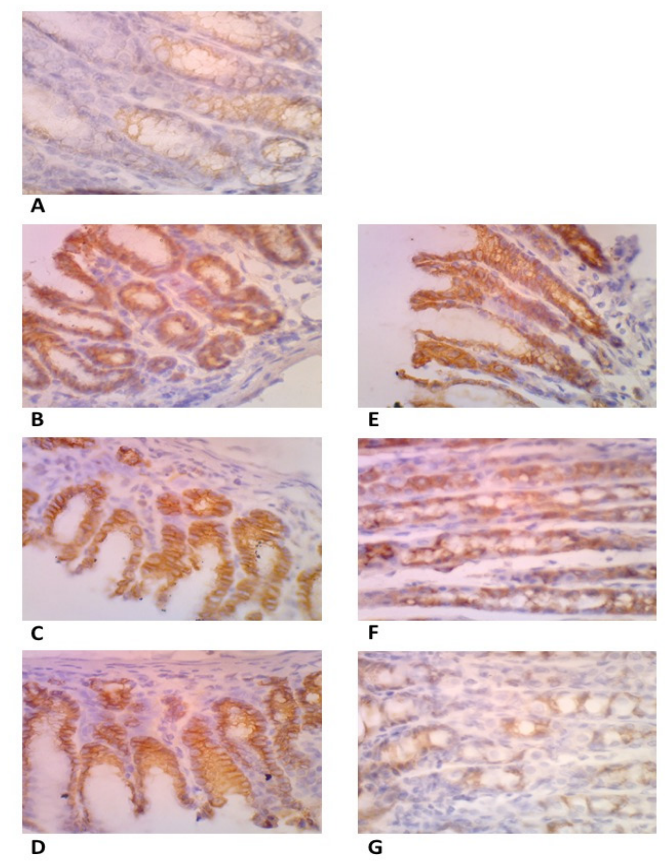

FIGURE 3. COX-2 expressions on gastric mucosa. A. Control group (CA); B. Ethanol $1^{\text {st }}$ day group $\left(\mathrm{ED}_{1}\right)$; C. Ethanol $3^{\text {rd }}$ day group $\left(\mathrm{ED}_{3}\right)$; D. Ethanol $5^{\text {th }}$ day group $\left(\mathrm{ED}_{5}\right)$; E. Aspirin $4^{\text {th }}$ day group $\left(\mathrm{AD}_{4}\right)$; F) Aspirin $6^{\text {th }}$ day group; G. Aspirin, $8^{\text {th }}$ day group $\left(\mathrm{AD}_{8}\right)$. Control group $(\mathrm{CA})$ and aspirin $8^{\text {th }}$ day group shown weak $\mathrm{COX}-2$ expression and the other $\left(\mathrm{ED}_{1}\right.$, $\mathrm{ED}_{3}, \mathrm{ED}_{5}, \mathrm{AD}_{4}$ and $\mathrm{AD}_{6}$ ) shown strong COX-2 expression. 400x magnification

\section{iNOS expression}

Shapiro Wilk test found abnormal distribution on iNOS expression data. The mean difference tested by using Kruskal Wallis shown that some of the groups had different means of iNOS expression score $(p=0.009 ; p<0.05)$. Further, Mann Whitney test was done to see the differences among the groups.

iNOS expression in ethanol or aspirin induced gastric mucosal damage can be seen in FIGURE 4. The CA group shown negative iNOS expression (FIGURE 4A) with the lowest mean score $(1.334 \pm 0.577)$, which represents the value for negative expression. The AH8 grouphad low iNOS expression (FIGURE 4G). The other groups ( $\mathrm{ED}_{1}, \mathrm{ED}_{3}$, $\mathrm{ED}_{5}, \mathrm{AD}_{4}$, and $\mathrm{AD}_{6}$ ) shown strong iNOS expression.

Mann Whitney test shown that all of the mean scores of iNOS expression of the treatment groups were significantly different with the CA group. Even though the other treatment groupshad different means of iNOS expression compared to control (CA), it can be divided into 3 categories. The highest mean score of iNOS expression was shown by the $\mathrm{ED}_{5}$ group $(6.000 \pm 0.000)$, followed by a cluster of $\mathrm{ED}_{1}, \mathrm{ED}_{3}$ and $\mathrm{AD}_{6}$ groups and the next category was a cluster of $\mathrm{AD}_{4}$ and $\mathrm{AD}_{8}$ groups (TABLE 10).

FIGURE 3. iNOS expressions on gastric mucosa. A. Control group (CA); B. Ethanol $1^{\text {st }}$ day group $\left(\mathrm{ED}_{1}\right) ; \mathrm{C}$. Ethanol $3^{\text {rd }}$ day group $\left(\mathrm{ED}_{3}\right) ; \mathrm{D}$. Ethanol $5^{\text {th }}$ day group $\left(\mathrm{ED}_{5}\right) ; \mathrm{E}$. Aspirin $4^{\text {th }}$ day group $\left.\left(\mathrm{AD}_{4}\right) ; \mathrm{F}\right)$ Aspirin $6^{\text {th }}$ day group; $G$. Aspirin, $8^{\text {th }}$ day group $\left(\mathrm{AD}_{8}\right)$. Control group (CA) and aspirin $8^{\text {th }}$ day group shown weak COX-2 expression and the other $\left(\mathrm{ED}_{1}, \mathrm{ED}_{3}, \mathrm{ED}_{5}, \mathrm{AD}_{4}\right.$ and $\left.\mathrm{AD}_{6}\right)$ showed strong COX-2 expression. 400x magnification 
TABLE 10. iNOS expression on induced gastric mucosal damage tissue

\begin{tabular}{cc}
\hline Group & Mean score \pm SD \\
\hline $\mathrm{CA}$ & $1.334 \pm 0.577$ \\
$\mathrm{ED}_{1}$ & $5.334 \pm 0.577$ \\
$\mathrm{ED}_{3}$ & $5.667 \pm 0.577$ \\
$\mathrm{ED}_{5}$ & $6.000 \pm 0.000$ \\
$\mathrm{AD}_{4}$ & $4.000 \pm 0.000$ \\
$\mathrm{AD}_{6}$ & $5.667 \pm 0.577$ \\
$\mathrm{AD}_{8}$ & $4.334 \pm 0.577$ \\
\hline
\end{tabular}

Interpretation: $0-2=$ negative expression, $>2$ $5=$ weak expression, $>5-8=$ strong expression

\section{DISCUSSION}

Gastric damage is caused by the imbalance of defensive and invasive factors for gastric acid production and result in over production. ${ }^{2}$ In this research, induction material such as $100 \%$ ethanol and aspirin as NSAID drugs were used to induce the gastric mucosal damage. Ethanol and aspirin are able to cause very severe mucosal damage compared to other material such as indomethacin and hydrochloric acid $(\mathrm{HCl})$. Previous study on indomethacin induced gastric mucosal damage shown that the gastric mucosal cells were unchanged after induction, while the induction using $80 \%$ ethanol and aspirin caused gastric mucosal cells hypertrophy. ${ }^{16}$

The most severe gastric mucosal damage found in this study was ulcers with bleeding (in groups $\mathrm{ED}_{1}$ and $\mathrm{AD}_{4}$ ). High ethanol concentration can induce ulcers in a relatively short time, therefore, the ulcer already could be seen on the first day after induction. Contrary to this pattern, aspirin can induce ulcers at low dosage and needs longer time, hence, the ulcer was gradually seen on the fourth day after induction. It has been explained in the previous study that the use of aspirin at lower dosage (75-300 mg) will gradually activate various disturbances of the digestion channel, such as dyspepsia, erosion of gastric wall, and ulcer with bleeding leading to perforation. ${ }^{15}$ Moreover, another study stated that lesions of gastric mucosa caused by NSAID including aspirin will attain the peak on the third day after induction and decrease in the $10^{\text {th }}$ day. ${ }^{17}$

Gastric ulcers are caused by local inflammation, which is initiated by the imbalanced production of mucus, bicarbonate and gastric acid resulting in gastric mucosa irritation. Further, the decreasing mucus production causes pepsin penetration to mucosal epithelium. ${ }^{18}$ Broken epithelium and continuous gastric acid production trigger inflammatory cytokine production, which activates macrophages. Macrophages will produce MCP-1 that causes the macrophages to induce the production of IL-1 $\beta$ and TNF- $\alpha$. This process causes the activation of the cytokine networking to trigger neutrophils migration from circulation to the inflammation area. ${ }^{8}$

More specifically, the gastric mucosal damage caused by ethanol occurs due to free radical production as the result of metabolism and local inflammation in the mucosa. Ethanol has a firm and easy penetration nature to the mucosal gastric layers. Various damages cause the accumulation of free radicals that trigger the imbalance of the production of ROS and antioxidant defense. ${ }^{19}$ This condition promotes oxidation stress accompanied by the reduction of PG resulting in the COX-2 activation to induce PG production. ${ }^{20}$

The process of gastric mucosal damage induced by aspirin needs longer time until the onset. Therefore, the ulcer appeared on the $4^{\text {th }}$ day after induction. Aspirin induced gastric ulcer was initiated by COX-1 inhibition by aspirin that causes the decreasing of $P G$ production and results in the disruption of blood flow in the mucosa. ${ }^{8}$ Mucosal erosion and ischemic injury as the consequences of the condition will induce COX-2 activation to increase the production of PG. ${ }^{21}$

The lighter spot ulcers appeared in groups $\mathrm{ED}_{3}, \mathrm{ED}_{5}, \mathrm{AD}_{6}$ and $\mathrm{AD}_{8}$. It seems that the healing process of mucosa was already started. The healing process in ethanol groups occurred earlier. Previous study explained that the mucosal healing 
process happened on the $3^{\text {rd }}$ day up to $18^{\text {th }}$ day or more. ${ }^{22,23}$ It involves the role of COX-2 as a mucosal gastro-protective factor. During inflammation, COX-2 will induce the production of $\mathrm{PG}$ that plays a role in ulcer healing process, angiogenesis, and increasing production of mucus and bicarbonate. ${ }^{21}$ Angiogenesis is an important process in the regeneration of blood vessels which are involved in oxygen and nutrient supply during microcirculation repair.

Inflammation and restoration of mucosa involves the role of COX-2 and iNOS. One study by Masayuki et al. ${ }^{21}$ explained that iNOS has a positive cell presence in the ulcer area with un-finished reepithelization. iNOS supplies new epithelial cells, covers the epithelial tissue eroded by the ulcer, and also acts as a barrier toward any pathogens. Several studies also mentioned that iNOS was a factor of angiogenesis that plays a role in microcirculation repair. Gastric mucosal damage that is represented by epithelial damage and the accumulation of acid reflux production would stimulate the production of inflammatory cytokines, including TNF- $\alpha$ and also induce the neutrophil infiltration. TNF- $\alpha$ and neutrophil infiltration would stimulate production of angiogenesis factors such as vascular endothelial growth factor (VEGF) and iNOS. ${ }^{22,24,25}$

During the angiogenesis process, endothelial cells undergo proliferation, migration, and regeneration to create new functional blood vessels. ${ }^{25}$ Angiogenesis is started on the $1^{\text {st }}$ day after the onset of mucosal damage, increases on the $3^{\text {rd }}$ day and decreases on the $10^{\text {th }}$ day. It is in line with iNOS expression, which is increased on the $3^{\text {rd }}$ day after the onset of mucosal damage and starts to decrease on the $10^{\text {th }}$ day. ${ }^{22}$ This study found similar results that iNOS expression in the ethanol groups appeared on the $1^{\text {st }}$ day after induction, when the gastric ulcer already occurred, while in the aspirin groups, iNOS expression can be observed on the $4^{\text {th }}$ day after induction, at the same time with the onset of the ulcer.

The iNOS expression in ethanol induced gastric ulcer continues to increase until the $5^{\text {th }}$ day since the onset of the ulcer $\left(\mathrm{ED}_{5}\right.$ group), while aspirin induced gastric ulcer showed increasing iNOS expression on the $3^{\text {rd }}$ day after onset $\left(\mathrm{AD}_{6}\right.$ group) and started to decline on the $5^{\text {th }}$ day after onset $\left(\mathrm{AD}_{8}\right.$ group). It is assumed that the process of gastric mucosal damage in ethanol induced ulcers is still occurring until the $5^{\text {th }}$ day after onset, while in aspirin induced ulcers it already starts the recovery process on the $5^{\text {th }}$ day after onset. From the explanation above, iNOS is an important factor for the healing process of gastric mucosal damage, therefore iNOS expression can be observed during the ulcer and the healing process with different levels of expression related to the level of damage and the stage of the healing process.

\section{CONCLUSION}

The damage process of ethanol induced gastric ulcers occurred faster than the one induced by aspirin. Contrary to this pattern, the recovery process of aspirin induced ulcers happened faster than the one induced by ethanol. It was also shown by the decreasing of iNOS expression in the aspirin $8^{\text {th }}$ day group ( $5^{\text {th }}$ day after onset $)$, while the iNOS expression in the ethanol $5^{\text {th }}$ day group ( $5^{\text {th }}$ day after onset) was still increasing. The highest COX-2 expressions in both ethanol or aspirin induced gastric ulcer groups were shown at the onset, $1^{\text {st }}$ day for ethanol and $4^{\text {th }}$ day for aspirin.

\section{ACKNOWLEDGEMENT}

The authors would like to thank Mr. Y. Suhardi, the laboratory technician in the Department of Histology, Faculty of Medicine, Public Health and Nursing UGM who provided valuable assistance during this research. 


\section{REFFERENCES}

1. Jain NK, Singh N, Kannojiya P, Garud N, Garud A, Tonpay SD. Pharmacological screening of antiulcer agent: a review. Int J Pharm Sci Res 2010; 1:29-37.

2. Farzaei MH, Khazaei M, Abbasabadei Z, Feyzmahdavi M, Mohseni GR. Protective effect of Tragopogon graminifolius DC against ethanol induced gastric ulcer. Iran Red Crescent Med J 2013; 15(9):813-6.

http://dx.doi.org/10.5812/ircmj.7845

3. Srivastava V, Mohan G, Viswanathswamy AHM. Protection of ethanol induced ulcers by sodium cromoglycate in albino rats. IJPER 2010; 46:29-33.

4. Atta AH, Soad MN, Samar MM. Antiulcerogenic effect of some plant extracts. Natural Product Radiance 2005; 4:258-63.

5. Matsui H, Shimokawa O, Kaneko T, Nagano Y, Rai K, Hyodo I. The pathophysiology of non-steroidal anti inflammatory drug (NSAID) induced mucosal injuries in stomach and small intestine. J Clin Biochem Nutr 2011; 48(2):107-11.

http://dx.doi.org/10.3164/jcbn.10-79

6. Odashima M, Otaka M, Jin M, Komatsu $\mathrm{K}$, Wada I, Horikawa Y, et al. Attenuation of gastric mucosal inflammation induced by aspirin through activation of A2A adenosine receptor in rats. World $\mathrm{J}$ Gastroenterol 2006; 12(4):568-73.

http://dx.doi.org/10.3748/wjg.v12.i4.568

7. Darling R1, Romero JJ, Dial EJ, Akunda JK, Langenbach R, Lichtenberger LM. The effects of aspirin on gastric mucosal integrity, surface hydrophobicity, and prostaglandin metabolism in cyclooxygenase knockout mice. Gastroenterology 2004; 127(1):94-104.

http://dx.doi.org/10.1053/j.gastro.2004.04.003

8. Arakawa $\mathrm{T}$, Watanabe $\mathrm{T}$, Tanigawa $\mathrm{T}$, Tominaga K, Fujiwara Y, Morimoto K. Qualityofulcerhealingingastrointestinal tract: Its pathophysiology and clinical relevance. World J Gastroenterol 2012; 18(35):4811-22. http://dx.doi.org/10.3748/wjg.v18.i35.4811

9. Hajrezaie M, Golbabapour S, Hassandarvish P, Gwaram NS, A Hadi $\mathrm{AH}$, Ali HM, et al. Acute toxicity and gastroprotection studies of a new schiff base derived copper (II) complex against ethanol-induced acute gastric lesions in rats. Plos One 2012; 7(12):51537.

http://dx.doi.org/10.1371/journal.pone.0051537

10. Qader SW, Abdulla MA, ChuaLS, Sirat HM, Hamdan S. Pharmacological mechanisms underlying gastroprotective activities of the fractions obtained from Polygonum minus in Sprague Dawley rats. Int J Mol Sci 2012; 13(2):1481-96. http://dx.doi.org/10.3390/ijms13021481

11. Sidahmed HM, Azizan AH, Mohan S, Abdulla MA, Abdelwahab SI, Taha MM. Gastroprotective effect of desmosdumotin C isolated from Mitrella kentii against ethanol-induced gastric mucosal hemorrhage in rats: possible involvement of glutathione, heat-shock protein-70, sulfhydryl compounds, nitric oxide, and anti-Helicobacter pylori activity. BMC Complement Altern Med 2013; 13:183. http://dx.doi.org/10.1186/1472-6882-13-183

12. Al-Qaraghuli AMS, Abdel Wahab EMN, Al-Ani IM, Faisal GG. Effects of Xiang Sha Yang Wei Wan on ethanol-induced gastric ulcer in spraguedawley rats: a histological study. IMJM 2013; 12(2):3-10.

13. Tadin T, Krpina K, Stifter S, Babarovic E, Fuckar Z, Jonjic N. Lower cyclooxygenase- 2 expression is associated with recurrence of solitary non-muscle invasive bladder carcinoma. Diag Pathol 2012; 7:152.

http://dx.doi.org/10.1186/1746-1596-7-152

14. Angelo AA, Hassan MA, Din NMNE, Khalifa HM, Ghany SAA. A possible role for gastroprotectives on aspirininduced gastric ulcer in rats. Bull Alex Fac Med 2010; 46(1):75-82.

15. Zhang JY, Wu QF, Wan Y, Song SD, $\mathrm{Xu}$ J, Xu XS, et al. Protective role of hydrogen-rich water on aspirin-induced gastric mucosal damage in rats. World $\mathrm{J}$ 
Gastroenterol 2014; 20(6):1614-22. http://dx.doi.org/10.3748/wjg.v20.i6.1614

16. Saputri FC, Sari SP, Mun'im A. Pengembangan metode induksi tukak lambung. Majalah Ilmu Kefarmasian 2008; 84-90.

17. Mishra CSK. Biotechnology Applications. IK. International Pvt Ltd. 2009; 115.

18. Allen A, Flemström G. Gastroduodenal mucus bicarbonate barrier: protection against acid and pepsin. Am J Physiol Cell Physiol 2005; 288(1):1-19. http://dx.doi.org/10.1152/ajpcell.00102.2004

19. Agarwal A, Gupta S, Sharma RK. Role of oxidative stress in female reproduction. Reprod Biol Endocrinol $2005 ; 3: 28$. http://dx.doi.org/10.1186/1477-7827-3-28

20. Unis A, Abdelzaher E. Sitaglipin impairs healing of experimentally induced gastric ulcers via inhibition of iNOS and COX-2 expression. Am J Pharmacol Toxicol 2013; 8(3):107-19. http://dx.doi.org/10.3844/ajptsp.2013.107.119

21. Brzozowski T, Konturek PC, Konturek SJ, Brzozowska I, Pawlik T. Role of prostaglandins in gastroprotection and gastric adaptation. J Physiol Pharmacol
2005; 56 (Suppl 5):33-55.

22. Tatemichi M, Ogura T, Sakurazawa N, Nagata H, Sugita M, Esumi H. Roles of inducible nitric oxide synthase in the development and healing of experimentally induced gastric ulcers. Int J Exp Pathol 2003; 84(5):213-20. http://dx.doi.org/10.1111/j.1365-2613.2003.00357.x

23. Halter F, Tarnawski AS, Schmassmann A, Peskar BM. Cyclooxygenase-2 implications on maintenance of gastric mucosal integrity and ulcer healing: controversial issues and perspectives. Gut 2001; 49(3):443-53. http://dx.doi.org/10.1136/gut.49.3.443

24. Lu P, Li L, Liu G, Baba T, Ishida Y, Nosaka M, et al. Critical role of TNF- $\alpha-$ induced macrophage VEGF and iNOS production in the experimental corneal neovascularization. Invest Ophthalmol Vis Sci 2012; 53(7):3516-26. http://dx.doi.org/10.1167/iovs.10-5548

25. Rahat MA, Hemmerlein B, Charyulu VI. The regulation of angiogenesis by tissue cell-macrophage interaction. Front Physiol 2014; 5(262):1-2. http://dx.doi.org/10.3389/fphys.2014.00262 